\title{
Upaya Peningkatan Aktivitas Belajar Siswa Melalui Model Pembelajaran Kooperatif Tipe Make A Match
}

\author{
Ni Kadek Okta Letriani*1, Lulup Endah Tripalupi ${ }^{2}$ \\ 1,2Program Studi Pendidikan Ekonomi \\ Universitas Pendidikan Ganesha \\ Singaraja, Indonesia
}

e-mail: oktaletriani@gmail.com¹, tripalupilulup@gmail.com²

Riwayat Artikel Tanggal diajukan: 22 April 2021

Tanggal diterima : 22 November 2021

Tanggal dipublikasikan 15 Desember 2021
Pengutipan: Letriani,, N. K. O. \& Tripalupi, L. E. (2021). Upaya Peningkatan Aktivitas Belajar Siswa Melalui Model

Pembelajaran Kooperatif Tipe Make A Match. Jurnal Pendidikan Ekonomi Undiksha, 13 (2), 300-309

http://dx.doi.org/1 $0.23887 /$ ijpe.v13i 2.33979

\begin{abstract}
Abstrak
Riset ini menghilangkan permasalahan di kelas XII C OTKP (Otomasi Manajemen Perkantoran) SMK Negeri 1 Singaraja, dimana aktivitas belajar siswa masih rendah. Untuk mengatasi masalah tersebut, peneliti mempelajari penerapan model pembelajaran kooperatif tipe "make a match". Tujuan dari riset ini adalah untuk mengetahui peninggian aktivitas belajar siswa kelas XII C OTKP SMK Negeri 1 Singaraja dengan penerapan mata pelajaran kemampuan dasar dan kewirausahaan kedua berdasarkan model pembelajaran kooperatif tipe matched. Riset ini memakai desain riset tindakan kelas (PTK). Memakai tata cara observasi dan dokumen untuk mengumpulkan data, dan menganalisa data melalui analisa statistik persentase sederhana. Capaian riset menunjukkan bahwasanya rata-rata integritas belajar siswa pada kegiatan pembelajaran putaran pertama sebesar $64,05 \%$, kemudian rata-rata integritas siswa pada kegiatan pembelajaran putaran kedua sebesar $84,08 \%$. Capaian riset ini membuktikan bahwasanya aktivitas belajar dapat meningkat setelah menerapkan model pembelajaran Kooperatif Tipe Make A Match di kelas XII C OTKP SMK Negeri 1 Singaraja.
\end{abstract}

Kata kunci: Pendidikan; Model Pembelajaran Kooperatif Tipe Make A Match; Aktivitas Belajar

\begin{abstract}
This study is different from the problems in the twelfth category C OTKP (Otomatisasi Tata Kelola Perkantoran) SMK Negeri 1 Singaraja, whose student learning activities are still relatively low. In order to overcome these problems, the application in type matching of cooperative learning models is studied. The purpose of this study is to determine the increase in learning activities of middle school students in the XII C OTKP SMK Negeri 1 Singaraja category by applying cooperative learning model type matching to the second basic ability of entrepreneurship subjects. This study used the "Classroom Action Research" design. Use observation methods and documents to collect data, and analyze the data through simple percentage statistical analysis. The results show that the average learning integrity obtained by the students in the first cycle of learning activities is $64.05 \%$, and the average learning integrity obtained in the second cycle is $84.08 \%$. Research results prove that learning activity can increase after applying Cooperative Learning Model Type Make A Match in class XII C OTKP SMK Negeri 1 Singaraja.
\end{abstract}

Keywords: Learning; Cooperative Learning Model Type Make A Match; Learning Activity 


\section{PENDAHULUAN}

Dalam proses pendidikan, kedudukan guru serta siswa berbeda- beda. Guru dalam aktivitas pendidikan dituntut buat bisa mengelola atmosfer kelas yang mengasyikkan. Supaya sukses belajar di kelas, guru wajib memilah model pendidikan yang menarik, efisien serta efektif. Di sisi lain, dalam proses pendidikan, siswa dituntut buat berfungsi aktif dalam aktivitas kelas. Dengan terdapatnya interaksi antara guru dengan siswa serta antara siswa dengan siswa hingga hendak diperoleh capaian belajar yang baik. Pendidikan tidak hendak bawa pergantian yang menarik untuk siswa, serta kerapkali hendak kurangi keikutsertaannya dalam proses pendidikan sehingga berdampak pada penyusutan kegiatan belajar siswa di dalam kelas.

Bagi Hamalik (2001)," pengajaran yang efisien merujuk pada pengajaran tentang peluang belajar yang bisa dicoba dalam aktivitas sendiri ataupun oleh diri sendiri". Guru wajib bisa memakai siswa selaku topik pendidikan supaya siswa bisa berfungsi aktif dalam proses pendidikan. Dalam proses pendidikan siswa yang aktif hendak bisa meraupkan modul pendidikan dengan baik. Lewat pelaksanaan bermacam model pendidikan, guru berfungsi berarti dalam tingkatkan kegiatan belajar siswa.

Dalam pemikiran Rusman, model pendidikan kooperatif model pendidikan yang sesuai ialah model pendidikan yang sesuai, sebab salah satu kelebihan dari teknologi ini ialah siswa bisa menciptakan pendamping sembari menekuni konsep ataupun topik dalam atmosfer yang mengasyikkan. Dalam atmosfer pendidikan, siswa tidak hendak merasa gugup sepanjang di kelas, namun hendak sangat tertarik serta menguasai modul yang dikenalkan. Tidak hanya itu," pendidikan pola pendidikan kooperatif" menuntut siswa buat silih berbicara di dalam kelas serta bertukar benak buat membongkar permasalahan yang dihadapinya, serta tiap siswa wajib mengenali jawaban yang sudah dikerjakannya. Tiap siswa secara otomatis merasa sanggup menanggapi pertanyaanpertanyaan ini.

Pelaksanaan model pendidikan diawali dengan tata cara yang menginstruksikan siswa buat mencari pendamping kartu saat sebelum batasan waktu, kartu tersebut ialah jawaban / persoalan, setelah itu membagi siswa yang sanggup mencocokkan kartu tersebut jadi sebagian kelompok dialog. Secara garis besar, "membangun model pendidikan kooperatif jenis yang serasi" ialah salah satu tata cara pendidikan mencari pendamping, siswa hendak mencari pendamping kala belajar. Diharapkan lewat teknologi ini, guru bisa membagikan peluang kepada siswa buat silih bertukar benak serta memikirkan jawaban yang sangat pas. Tidak hanya itu, keahlian yang tercantum di dalamnya mendesak siswa buat mempunyai jiwa gotong royong.

Keunggulan model pendidikan kooperatif jenis make a match ini ialah pendidikan hendak lebih menarik sebab terdapatnya elemen game yang membuat siswa puas dengan pendidikan, Dengan silih menolong dalam menguasai modul, uraian siswa terhadap modul yang diteliti bisa ditingkatkan. Siswa yang bekerja dalam kelompok bisa menuntaskan tugas dengan bersemangat, sehingga tingkatkan motivasi belajar yang awal mulanya rendah. Tata cara ini pula ialah tata cara terbaik buat tingkatkan tanggung jawab individu dalam kelompok.

Capaian observasi di SMK Negeri 1 Singaraja di kelas XII C OTKP pada saat berlangsung proses pembelajaran kewirausahaan masih dijumpai siswa yang tidak serius dalam mengikuti proses membelajaran. Perihal ini tampak pada rendahnya aktivitas belajar yang mereka lakukan. Masih kurangnya pemahaman materi di kelas yang diakibatkan karena siswa jarang mengulang kembali pembelajaran di rumah bahkan tidak ingin mencari tahu solusi dari materi yang kurang dipahami. Perihal ini yang membuat siswa kurang siap dalam belajar di kelas saat pembelajaran dimulai. Ketika ditanya kembali oleh guru tentang materi yang dibahas, jarang sekali siswa yang berani menjawab dan bertanya kembali. Meskipun berulang kali ditegur oleh guru, siswa masih saja mengambil kesempatan untuk tidak mendengarkan pembelajaran di kelas. Ini yang mengakibatkan aktivitas belajar di dalam kelas ini masih kurang. Salah satu model pembelajaran yang dipakai peneliti untuk meningkatkan aktivitas pembelajaran 
p-ISSN : 2599-1418

e-ISSN : 2599-1426

kewirausahaan pada kategori OTKP XII C adalah model pembelajaran kooperatif tipe matching.

Oleh karena itu, peneliti tertarik untuk melakukan riset tindakan kelas (PTK) untuk menyelesaikan masalah belajar siswa dengan menerapkan "model pembelajaran kooperatif tipe berpasangan" (pairing), dengan tujuan untuk meningkatkan aktivitas pembelajaran kewirausahaan siswa OTKP XII C SMK Negeri 1 Singaraja. Adapun judul riset ini, yaitu "Upaya Peninggian Aktivitas Belajar Siswa melalui Model Pembelajaran Kooperatif Tipe Make A Match".

\section{METODE}

Riset ini memakai desain riset aksi kelas (PTK). Dalam rangka tingkatkan kegiatan belajar siswa lewat pelaksanaan model pendidikan kooperatif, diadakan perlombaan. Dalam riset ini dipakai dekat 2 siklus, ialah siklus yang dipecah jadi 4 bagian, ialah sesi perencanaan aksi, sesi penerapan aksi, sesi observasi aksi, serta sesi refleksi aksi.

Posisi riset ini ialah Sekolah Menengah Kejuruan (SMK) Negeri 1 Singaraja di Jalan. Pramuka 6 Singaraja, Buleleng, Bali. Subjek riset ini ialah 22 siswa kelas XII C OTKP. Tujuan dari riset ini ialah pelaksanaan model pendidikan kooperatif jenis matching permainan serta aktivitas pendidikan. Setelah itu riset ini memakai jenis informasi kuantitatif. Sehabis diterapkan model pendidikan" matching type cooperation", informasi kuantitatif bisa membangkitkan kegiatan pendidikan. Sumber informasi yang dipakai ialah informasi asli. Informasi utama model pendidikan kooperatif tipe pencocokan diperoleh dari informasi kegiatan pendidikan.

Tata cara pengumpulan informasi kegiatan pendidikan memakai tata cara observasi bersama dengan instrumen lembar observasi. Sehabis informasi terkumpul hendak dianalisa dengan memakai analisa informasi deskriptif kuantitatif. Langkah- langkah yang dicoba buat menganalisa informasi kuantitatif ialah selaku berikut.

Pertama, tentukan kriteria penilaian untuk setiap parameter kegiatan yang
Jurnal Pendidikan Ekonomi Undiksha

Vol. 13 No. 2 (2021)

diamati. Kedua, jumlahkan skor masingmasing parameter aktivitas pembelajaran yang diamati. Ketiga, memakai rumus untuk menghitung skor setiap parameter kegiatan pembelajaran yang diamati:

$\ldots . . \%=\frac{\text { Jumlah skor indikator }}{\text { Skor maksimum }} \times 100$

Sugiyono (2015)

Rencana program riset aksi kelas meliputi 2 siklus, serta tiap siklus meliputi 4 tahapan ialah perencanaan, penerapan, observasi serta refleksi. Bila sasaran kebercapaianan tidak tercapai, pendidikan hendak dilanjutkan ke siklus selanjutnya. Dalam melaksanakan riset ini, periset dibantu dengan 3 observasi.

Pada siklus awal, aku membagi tahapan selaku berikut:

Awal, sesi persiapan ialah menyusun rencana kurikulum buat produk kreatif serta tema kewirausahaan, serta memastikan media KD ketiga ialah mempersiapkan tabel observasi serta sediakan bahan ajar.

Kedua, sesi aksi, tahap- tahap pada sesi ini merujuk pada rencana berbasis RPP.

Ketiga, sesi observasi, ialah observasi sepanjang penerapan proses pendidikan di kelas dengan tata cara pemberian skor pada kertas observasi yang sudah disiapkan.

Keempat, sesi refleksi, ialah aktivitas refleksi yang dicoba lewat dialog antara guru dengan pengamat, mengevaluasi capaian aksi yang sudah dicoba, hambatan yang timbul, serta mengevaluasi capaian aksi. Capaian refleksi dipakai buat membetulkan aktivitas siklus selanjutnya. Bila pengoperasian pada siklus I tidak menampakkan capaian terbaik, aksi korektif wajib dicoba pada siklus selanjutnya.

Siklus kedua meliputi tahapan selaku berikut:

Awal, sesi perencanaan, umumnya sesi perencanaan kedua, nyaris sama dengan sesi perencanaan awal. Perbedaannya terletak pada revisi yang butuh dicoba bersumber pada capaian implementasi putaran pertama.

Kedua, tahapan penerapan aksi ialah tahapan ini nyaris sama dengan tahapan 
p-ISSN : 2599-1418

e-ISSN : 2599-1426

penerapan aksi pada siklus I, serta guru melakukan desain pendidikan cocok RPP.

Pada siklus II sudah direncanakan revisi capaian refleksi pada siklus I.

Ketiga, sesi observasi, ialah mengamati sepanjang proses pendidikan di kelas, serta membagikan skor pada tabel observasi pada siklus II.

Keempat, melaksanakan sesi refleksi, siklus II refleksi, buat mengenali perbandingan capaian siklus I serta siklus II. Bila terjalin kenaikan kegiatan belajar siswa sepanjang siklus ini, hingga tidak butuh mengulang siklus tersebut. Bersumber pada capaian refleksi siklus II, pengamat bisa menarik konklusi tentang capaian aksi yang dicoba pada siklus awal serta kedua.

Bila sesuatu aksi bisa penuhi kriteria kebercapaianan minimum yang sudah didetetapkan, aksi tersebut dikira sukses. Dalam proses ini, bila seluruh ataupun paling tidak sebagian besar $(75 \%)$ siswa berpartisipasi aktif dalam proses pendidikan secara raga, psikologis serta sosial, hingga pendidikan sukses serta bermutu Mulyasa (2009). Penanda kebercapaianan pendidikan ialah aktivitas pendidikan yang dilaksanakan lewat model pendidikan kooperatif jenis“ matching" buat menggapai standar kebercapaianan minimun yang sudah diresmikan ialah $\geq 75 \%$.

\section{HASIL DAN PEMBAHASAN \\ Data Aktivitas Belajar Siswa Siklus I}

Pelaksanaan model pendidikan berpasangan putaran awal dalam pendidikan kreatif serta produk kewirausahaan pada 22 siswa pada pelajaran XII OTKP Sekolah Menengah Kejuruan (SMK) Negeri 1 Singaraja. Tahapan riset pada siklus I ialah selaku berikut. Awal, pada sesi perencanaan ini, penataan serta perencanaan produk kreatif serta wirausaha dicoba dengan mempraktikkan model pendidikan kooperatif jenis make match. Tidak hanya itu, periset berdiskusi serta bertanya dengan guru mata pelajaran tentang masalah- masalah yang berasosiasi dengan rencana yang dibesarkan oleh periset. Periset serta guru sudah menggapai konvensi kalau modul utama yang hendak dipelajari pada siklus I ialah memastikan media promosi.
Jurnal Pendidikan Ekonomi Undiksha

Vol. 13 No. 2 (2021)

Kedua, sesi penerapan aksi ialah pelaksanaan dari sesi perencanaan yang sudah dicoba. Penerapan pendidikan

dengan pelaksanaan model pendidikan kooperatif jenis make a match pada siklus I dilaksanakan sepanjang 3 jam pelajaran dalam satu kali pertemuan.

Ketiga, sesi pengamatan dicoba bertepatan dengan penerapan aksi siklus I, dengan tujuan buat mengamati kegiatan belajar cocok dengan pedoman observasi yang sudah didetetapkan. Objek pengamatannya ialah kegiatan belajar siswa. Bersumber pada capaian pengamatan tentang kegiatan belajar siswa bisa dikenal kalau penanda yang belum penuhi kriteria kebercapaianan pendidikan $(75 \%)$ ialah, membaca modul pelajaran (43, 93\%), mengamati/ mencermati penyampaian modul $(72,72 \%)$, bertanya terpaut modul yang di informasikan $(68,18 \%)$, mengantarkan komentar/ anjuran/ jawaban/ sanggahan terpaut mata pelajaran (40,90\%), melaksanakan dialog kelompok $(69,69 \%)$, mencermati uraian guru $(71,21 \%)$, mencermati komentar/ data dalam dialog $(72,72 \%)$, menulis ulasan modul atas apa yang sudah disabilan $(63,33 \%)$, menulis jawaban atas tugas/ soal yang diberikan $(74,24 \%)$, serta menyumbangkan ilham pemecahan permasalahan $(63,63 \%)$.

Keempat, sesi refleksi diperoleh 10 penanda kegiatan belajar siswa belum menggapai kriteria kebercapaianan yang didetetapkan (75\%). Nilai rata- rata buat skor kegiatan belajar siswa yang diperoleh baru menggapai $64,05 \%$ sepanjang penerapan siklus I, ada sebagian kasus yang dialami, selaku berikut:

Pertama, bagaikanan besar siswa tidak membawa buku pelajaran dikarenakan jumlah buku panduan yang diberikan oleh pihak sekolah terbatas, jadi siswa diminta untuk memakai 1 buku untuk 2 orang. Bila salah satu siswa tidak membawa akan berdampak juga pada temannya yang duduk sebangku. Periperihal ini berakibat pada rendahnya skor penanda membaca modul.

Kedua, bagaikanan siswa masih kurang berani bertanya serta mengantarkan komentar/ anjuran/ jawaban/ sanggahan. Perihal ini dikarenakan siswa masih kurang percaya diri apakah pertanyaan atau 
p-ISSN : 2599-1418

e-ISSN : 2599-1426

sanggahan yang akan disampaikan nanti benar atau salah, jadi siswa lebih memilih diam dan hanya menganggukan kepala bila ditanya apakah sudah memahami materi. Sehingga periperihal ini berakibat pada rendahnya kegiatan bertanya serta mengantarkan pendapat.

Ketiga, siswa masih malu-malu dalam melakukan diskusi untuk mencari pasangan jawaban dari soal yang telah dibagikan. Perihal ini dikarenakan saat siswa diarahkan mencari pasangan ada beberapa yang bertemu lawan jenis yang mengakibatkan siswa menjadi kurang percaya diri dan malumalu untuk mencocokkan jawaban. Inilah yang mengakibatkan banyak waktu yang terbuang untuk mencocokkan jawaban.

Keempat, sebagian siswa tidak mencatat modul yang sudah di informasikan guru, sehingga kegiatan menulis cenderung rendah. Perihal ini diakibatkan sebagian siswa tidak fokus mendengarkan materi yang dipaparkan, sehingga saat siswa diarahkan untuk mencatat perihal-perihal penting dalam penyampaian materi, siswa menjadi bingung.

Keempat, sebagian siswa tidak mencatat modul yang sudah di informasikan guru, sehingga kegiatan menulis cenderung rendah.

Kelima, aktivitas menyumbangkan ilham pemecahan permasalahan pula rendah. Siswa memilah sepakat supaya tidak ditunjuk buat mengemukakan komentar yang lain. Periperihal ini terjalin pada dikala usai melakukan persentasi, cuma sebagian siswa saja yang bertanya serta membagikan sanggahan atas capaian dialog.

Dari capaian refleksi kalau butuh dicoba perbaikan- perbaikan dalam penerapan aksi pada siklus II. Revisi penerapan siklus I selaku berikut:

Awal, guru menginformasikan siswa buat bawa novel panduan pada pertemuan berikutnya serta membagikan peluang kepada siswa buat mencari/ membaca dari bermacam sumber sehingga tidak terpaku pada materi saja.

Kedua, guru membagikan motivasi serta dorongan kepada siswa dalam bertanya serta mengantarkan komentar/ anjuran/ jawaban/ sanggahan.
Jurnal Pendidikan Ekonomi Undiksha

Vol. 13 No. 2 (2021)

Ketiga, guru pula membagikan motivasi dengan membagikan waktu 2 menit buat mencocokan jawaban supaya siswa lebih aktif serta semangat dalam mencari pasangannya. Bila siswa diberikan batas waktu, siswa lebih bersemangat dan tidak akan malu-malu bila menemukan pasangan yang berlawanan jenis. Siswa yang lebih cepat menemukan pasangan juga akan diberikan poin tambahan oleh guru. Solusi ini untuk masalah poin ketiga pada tahap refleksi.

Keempat, guru membagikan arahan kalau tiap siswa wajib mempunyai catatan dari tiap modul yang sudah di informasikan. Periperihal ini dicoba buat tingkatkan kegiatan menulis pada siswa.

Kelima, guru membagikan motivasi siswa buat tingkatkan rasa yakin diri buat berpartisipasi aktif dalam dialog sehingga tidak terdapat siswa yang merasa lebih unggul dari yang lainnya.

\section{Data Aktivitas Belajar Siswa Siklus II}

Keempat, guru membagikan arahan kalau tiap siswa wajib mempunyai catatan dari tiap modul yang sudah di informasikan. Periperihal ini dicoba buat tingkatkan kegiatan menulis pada siswa.

Kelima, guru membagikan motivasi siswa buat tingkatkan rasa yakin diri buat berpartisipasi aktif dalam dialog sehingga tidak terdapat siswa yang merasa lebih unggul dari yang lainnya

Pelaksanaan model pendidikan kooperatif jenis make a match siklus II pada pendidikan produk kreatif serta kewirausahaan di kelas XII C OTKP Sekolah Menengah Kejuruan (SMK) Negeri 1 Singaraja dengan modul pokok media promosi online. Jumlah siswa yang muncul 22 siswa. Tahapan riset siklus II ialah selaku berikut. Awal, Sesi perencanaan pada siklus II tidak jauh beda dengan sesi perencanaan pada siklus I. Sesi perencanaan pada siklus II dilaksanakan bersumber pada capaian dari tahan refleksi siklus I. Revisi pada siklus I tersebut bersumber pada konvensi periset serta guru mata pelajaran sehabis melaksanakan refleksi serta penilaian. Siklus II dilaksanakan buat membetulkan dan tingkatkan capaian yang sudah diperoleh pada siklus I supaya capaiannya lebih optimal. 
p-ISSN : 2599-1418

e-ISSN : 2599-1426

Kedua, sesi penerapan aksi pada siklus II tidak jauh berbeda dengan sesi penerapan aksi pada siklus I. penerapan pendidikan dengan pelaksanaan model pendidikan kooperatif jenis make a match pada siklus II dilaksanakan 3 jam pelajaran dalam satu kali dengan modul pokok media promosi online.

Ketiga, sesi pengamatan siklus II sama dengan siklus I, ialah bertepatan dengan proses pendidikan serta objeknya berbentuk kegiatan belajar siswa sepanjang pendidikan di kelas XII C OTKP Sekolah Menengah Kejuruan (SMK) Negeri 1 Singaraja.

Keempat, sesi refleksi diperoleh capaian riset pada siklus II, penerapan aksi pada siklus II sudah cocok dengan perencanaan serta berjalan dengan baik. Hambatan yang ditemui ialah permasalahan pengkondisian siswa di dini pendidikan. Sebagian siswa terdapat yang telat masuk kelas serta pendidikan sedikit diundur.

Kelemahan- kelemahan pada siklus II bisa teratasi dengan baik. Periperihal ini bisa diamati dari capaian pengamatan yang menampakkan kalau seluruh penanda kegiatan belajar siswa kelas XII C OTKP Sekolah Menengah Kejuruan (SMK) Negeri 1 Singaraja sudah menggapai kriteria keberasilan minimun yang didetetapkan. Capaian riset menampakkan kalau pelaksanaan model pendidikan kooperatif jenis make a match sudah tingkatkan kegiatan belajar siswa dari siklus I ke siklus II. Bersumber pada periperihal tersebut, bisa dikonklusikan kalau penerapan riset aksi kelas dengan memakai model pendidikan kooperatif jenis make a match dikira sukses buat tingkatkan kegiatan belajar siswa kelas XII C OTKP Sekolah Menengah Kejuruan (SMK) Negeri 1 Singaraja tahun ajaran 2019/2020.

Informasi kegiatan belajar siswa dari siklus I ke siklus II hadapi peninggian pada tiap parameternya. Berikut rincian menimpa kegiatan belajar siswa kelas XII C OTKP Sekolah Menengah Kejuruan (SMK) Negeri 1 Singaraja pada tiap parameternya.

Awal, penanda membaca modul pelajaran serta bahan dialog. Modul yang dipakai pada aktivitas pendidikan ialah berbentuk materi/ novel panduan yang dipunyai siswa. Terjalin kenaikan skor
Jurnal Pendidikan Ekonomi Undiksha

Vol. 13 No. 2 (2021)

kegiatan belajar siswa membaca modul pelajaran serta bahan dialog bersumber pada informasi pengamatan dari siklus I ke

siklus II sebesar 43,94\%. Periperihal ini ditunjukkan dari skor kegiatan belajar siswa membaca modul pelajaran serta bahan dialog yang diperoleh di siklus I dengan persentase sebesar 43,93\% serta persentase pada siklus II sebesar $87,87 \%$. Pada siklus I sebagian siswa tidak bawa novel panduan yang biasa dipakai acuan dalam pendidikan. Pada sesi refleksi siklus I, dicoba penilaian buat membetulkan kekurangan siklus I pada siklus II. Sehabis dicoba refleksi pada siklus I, terjalin kenaikan kegiatan membaca modul pelajaran. Pada siklus II banyak siswa yang membaca novel panduan. Kala siswa hadapi kesusahan dalam memecakan permasalahan hingga siswa hendak mencari jawabannya di novel panduan. Dengan kegiatan membaca siswa lebih mengenali banyak pengetahuan.

Kedua, penanda mengamati/ mencermati penyampaian modul. Kegiatan mengamati/ mencermati penyampaian modul dari guru pada siklus I ke siklus II sudah hadapi kenaikan sebesar $12,12 \%$. Periperihal ini ditunjukkan dari skor kegiatan belajar siswa mengamati/ mencermati penyampaian modul oleh guru yang diperoleh pada siklus I dengan persentase $72,72 \%$ serta persentase pada siklus II sebesar $84,84 \%$. Penyampaian modul tersebut bertujuan buat membagikan bekal uraian kognitif siswa.

Ketiga, penanda bertanya terpaut modul yang di informasikan. Terjalin kenaikan skor kegiatan belajar bertanya terpaut modul yang di informasikan bersumber pada informasi pengamatan dari siklus I ke siklus II sebesar 19,69\%. Periperihal ini ditunjukkan dari skor kegiatan belajar bertanya terpaut modul yang di informasikan yang diperoleh pada siklus I dengan persentase sebesar $68,18 \%$ serta pada siklus II sebesar $87,87 \%$. Persoalan yang diajukan siswa banyak yang diajukan kepada guru ataupun kepada rekan anggota kelompok dikala berdiskusi. Apabila dalam dialog permasalahan tidak terpecahkan 
p-ISSN : 2599-1418

e-ISSN : 2599-1426

hingga siswa hendak mengajukan persoalan kepada guru.

Keempat, penanda mengantarkan komentar/ anjuran/ jawaban/ sanggahan terpaut mata pelajaran. Pada siklus I kegiatan mengantarkan komentar/ anjuran/ jawaban/ sanggahan terpaut modul pelajaran baru menggapai 40,90\%. Setelah itu pada siklus II guru membagikan pancingan kepada siswa supaya aktif dalam mengantarkan komentar. Pada siklus II persentase kegiatan mengantarkan komentar bertambah jadi 80,30\%.

Bersumber pada informasi pengamatan terjalin kenaikan persentase kegiatan mengantarkan komentar/ anjuran/ jawaban terpaut mata pelajaran dari siklus I ke siklus II sebesar 39,40\%.

Kelima, penanda melaksanakan dialog. Terjalin kenaikan skor kegiatan belajar dialog bersumber pada informasi pengamatan dari siklus I ke siklus II sebesar $10,61 \%$. Periperihal ini ditunjukkan dengan skor kegiatan melaksanakan dialog yang diperoleh pada siklus I dengan persentase sebesar $69,69 \%$ serta persentase pada siklus II sebesar $80,30 \%$. Pada siklus I dialog belum menggapai kriteria kebercapaianan minimum disebabkan siswa masih malumalu mencari pendamping buat mencocokan soal serta jawaban. Dengan terdapatnya refleksi siklus I, guru bisa lebih mengendalikan jalannya dialog dengan tata cara membagikan batasan waktu serta motivasi dikala mencocokan soal serta jawaban.

Keenam, penanda mencermati uraian guru. Kegiatan mencermati uraian guru pada siklus I meraupkan skor $71,21 \%$, serta hadapi kenaikan pada siklus II sebesar $13,63 \%$ jadi $84,84 \%$. Guru membagikan modul uraian tidak cuma bersumber pada pada materi sehingga siswa jadi bersemangat serta bisa tingkatkan kegiatan mencermati uraian guru.

Ketujuh, penanda mencermati komentar/ data dalam dialog. Terjalin kenaikan skor kegiatan mencermati komentar/ data dalam dialog dengan persentase sebesar $13,64 \%$. Periperihal tersebut nampak dari perolehan skor kegiatan pada siklus I sebesar $72,72 \%$ serta pada siklus II sebesar $86,36 \%$. Pada siklus II hadapi kenaikan yang menunjukkan kalau
Jurnal Pendidikan Ekonomi Undiksha

Vol. 13 No. 2 (2021)

siswa telah mulai menguasai komentar orang lain dikala dialog berlangsung.

Kedelapan, penanda menulis ulasan modul atas apa yang sudah disabilan. Terjalin kenaikan skor kegiatan menulis ulasan modul yang sudah disabilan dari siklus I ke siklus II sebesar 18,48\%. Periperihal ini ditunjukkan dari skor kegiatan menulis ulasan modul atas apa yang sudah disabilan yang diperoleh dari siklus I dengan persentase sebesar $63,33 \%$ serta persentase pada siklus II sebesar $81,81 \%$. Bersumber pada refleksi pada siklus I, pada siklus II guru membagikan uraian modul tidak cuma cocok dengan materi namun menambakan data dari sumber lain yang menyebabkan siswa jadi bersemangat buat menulis uraian tersebut. Bersumber pada periperihal tersebut menyebabkan kegiatan menulis bertambah pada siklus II.

Kesembilan, penanda menulis jawaban atas tugas/ soal yang diberikan. Skor kegiatan pada siklus I sebesar $74,24 \%$ serta pada siklus II hadapi peninggian sebesar 09,09\% sehingga jadi 83,33\%. Pada siklus II guru lebih menekankan kepada siswa buat lebih lebih efisien dalam aktivitas tulis menulis. Sebab dengan aktivitas menulis siswa lebih kilat mengingat serta menguasai penyelesaian soal yang diberikan.

Kesepuluh, penanda menyumbangkan ilham pemecahan permasalahan. Penanda menyumbangkan ilham pemecahan permasalahan ialah kegiatan mental siswa buat mengukur keahlian siswa dalam menyumbangkan ilham pemecahan permasalahan. Skor kegiatan menyumbangkan ilham pada siklus I sebesar $63,63 \%$. Periperihal ini berarti skor kegiatan menyumbangkan ilham pemecahan permasalahan pada siklus I belum menggapai penanda kebercapaianan. Sehabis dicoba refleksi pada siklus I hingga disepakati diadakan revisi siklus II. Guru berupaya berikan motivasi siswa buat tingkatkan rasa yakin diri. Usaha tersebut pada siklus II membuahkan capaian dengan meningkatnya kegiatan menyumbangkan ilham pemecah permasalahan sebesar $19,70 \%$ sehingga persentase skor kegiatan menyumbangkan ilham jadi 83,33\%. 
Secara universal kegiatan belajar siswa dari siklus I ke siklus II dikatakan bertambah. Periperihal ini disebabkan kriteria tingkatan kebercapaianan telah tercapai. Jadi model pendidikan kooperatif jenis make a match bisa tingkatkan kegiatan belajar siswa kelas XII C OTKP Sekolah Menengah Kejuruan (SMK) Negeri 1 Singaraja.

Capaian riset menampakkan kalau model pendidikan kooperatif jenis make a match bisa tingkatkan kegiatan belajar siswa kelas XII C OTKP Sekolah Menengah Kejuruan (SMK) Negeri 1 Singaraja, yang ditunjukkan dari skor kegiatan belajar siswa dari siklus I ke siklus II hadapi kenaikan. Alibi terbentuknya kenaikan kegiatan belajar siswa sebab pada dikala diterapkan di kelas oleh periset nyatanya model pendidikan kooperatif jenis make a match menjadikan siswa aktif, bersemangat, serta membuat atmosfer mengasyikkan dikala proses pendidikan. Siswa nampak aktif dalam pembelajara paling utama pada saar tiaptiap siswa mencari pendamping kartu yang cocok dengan kartu yang mereka pegang. Siswa nampak bahagia dikala mencari pendamping serta menerima pujian dari guru, sehingga menimbulkan atmosfer pendidikan jadi mengasyikkan. Siswa nampak bersemangat buat belajar serta tidak terdapat siswa yang nampak bosan menjajaki pendidikan. Periperihal ini merujuk searah dengan komentar Huda (2014) yang melaporkan kalau model make a match bisa tingkatkan tingkatkan kegiatan belajar siswa, tingkatkan uraian siswa terhadap modul yang dipelajari, efisien buat melatih keberanian siswa, serta melatih ketertiban siswa buat menghargai waktu belajar.

Alibi lain terbentuknya kenaikan kegiatan belajar diakibatkan sebab pada dikala model pendidikan kooperatif jenis make a match diterapkan di kelas oleh periset, nyatanya siswa meraupkan pengalaman langsung dikala proses pendidikan. Apabila siswa memperoleh pengalaman langsung dikala proses pendidikan, hingga siswa hendak lebih gampang buat menciptakan style belajarnya sendiri dan siswa lebih gampang menguasai modul yang dipaparkan. Dengan terdapatnya pengalaman langsung ini, interaksi antara siswa dengan guru, siswa dengan siswa hendak nampak jelas. Interaksi yang terjalin ini hendak mendesak siswa buat termotivasi buat belajar sehingga dampaki terhadap kegiatan belajar yang timbul dikala proses pendidikan. Bila siswa mempunyai kegiatan belajar yang besar, hingga dia sanggup tingkatkan capaian kompetensi pengetahuan yang diperoleh siswa. Periperihal ini merujuk searah dengan komentar Lie (2002) kalau model pendidikan kooperatif jenis make a match bisa tingkatkan partisipasi siswa, lebih banyak peluang buat donasi tiap- tiap anggota kelompok, serta interaksi lebih gampang. Dengan mencermati komentar Huda (2014) serta Lie (2002) di atas, apabila pendidikan telah terjalin dalam atmosfer yang mengasyikkan serta pada dikala pendidikan siswa ikut serta secara langsung hingga pendidikan tersebut jadi bermakna untuk siswa serta dengan pengalaman langsung yang dipunyai oleh siswa mempermudah siswa buat tingkatkan kegiatan belajarnya.

Alibi lain terbentuknya kenaikan kegiatan belajar diakibatkan sebab pada dikala model pendidikan kooperatif jenis make a match diterapkan di kelas oleh periset, siswa diberikan peluang buat bertanggung jawab hendak tugas yang diberikan serta silih berkolaborasi dengan temannya buat menuntaskan kasus. Lewat aktivitas tersebut siswa berupaya buat menuntaskan kasus yang diberikan dengan mencari pendamping kartu yang cocok. Ini nampak pada fase mencari pendamping kartu. Pada fase ini siswa nampak perilaku silih berkolaborasi antara siswa serta pula menampakkan tanggung jawab dalam menuntaskan kasus tersebut. Aktivitas ini pastinya sanggup meningkatkan kegiatan belajar siswa serta pula dampaki capaian pendidikan yang diperoleh siswa. Periperihal ini merujuk searah dengan Suatnaya (2015) yang melaporkan kalau model pendidikan kooperatif jenis make a match ialah aktivitas yang menuntut kerjasama siswa buat silih menolong dalam menuntaskan perkara. Dengan terdapatnya kerjasama, siswa mempunyai kegiatan belajar yang lebih baik.

Alibi lain terbentuknya kenaikan kegiatan belajar diakibatkan sebab terdapatnya penghargaan buat siswa, 
p-ISSN : 2599-1418

e-ISSN : 2599-1426

sehingga bisa tingkatkan motivasi siswa buat belajar. Pemberian penghargaan berbentuk tepuk tangan serta pujian bisa membangkitkan semangat siswa buat belajar. Dengan terdapatnya semangat siswa buat belajar hendak menjadikan siswa lebih aktif serta bersemangat buat belajar, sehingga tujuan pendidikan yang diharapkan bisa tercapai serta capaian belajar siswa bisa bertambah. Dalam pelaksanaan model pendidikan kooperatif jenis make a match, penghargaan diberikan kepada siswa yang bisa mencari pendamping kartu yang diperolehnya dengan benar serta pas waktu. Periperihal ini merujuk searah dengan komentar Rifa'i (2018) kalau pelaksanaan penghargaan hendak sangat diperlukan oleh siswa dalam tingkatkan motivasi belajar siswa, setelah itu motivasi tersebut memiliki peranan berarti dalam kegiatan belajar siswa.

Capaian riset ini cocok dengan capaian riset terdahulu yang dicoba oleh Nurhabibah dan Alexon (2017), yang menciptakan kalau pelaksanaan model pendidikan jenis Make a Match bisa tingkatkan kegiatan dalam pendidikan. Senada dengan itu, capaian riset yang dicoba oleh Ningtyas dan Wuryani (2017) pula menciptakan kalau model pendidikan kooperatif jenis Make- A Match berbantuan media novel interaktif bisa tingkatkan kegiatan belajar siswa. Capaian yang sama pula ditunjukkan oleh capaian riset Paneo (2019) model pendidikan kooperatif jenis Make a Match (mencari pendamping) bisa tingkatkan kegiatan belajar siswa. Capaian riset oleh Zakiah, Prasetyo, dan Astutiningtyas (2019) pula menampakkan capaian yang sama kalau model pendidikan kooperatif jenis Make- A Match bisa tingkatkan kegiatan belajar siswa.

\section{SIMPULAN DAN SARAN}

Bersumber pada capaian serta ulasan bisa ditarik konklusi kalau pelaksanaan model pendidikan kooperatif jenis make a match bisa tingkatkan kegiatan belajar siswa kelas XII C OTKP Sekolah Menengah Kejuruan (SMK) Negeri 1 Singaraja. Periperihal tersebut bisa dibuktikan dengan jumlah siswa yang sudah menggapai skor kegiatan belajar dari siklus I ke siklus II. Informasi capaian pengamatan
Jurnal Pendidikan Ekonomi Undiksha

Vol. 13 No. 2 (2021)

menampakkan skor rata- rata kegiatan belajar siswa pada siklus I sebesar $64,05 \%$ bertambah jadi sebesar $84,08 \%$ pada siklus II. Periperihal tersebut menujukkan kalau kegiatan belajar siswa hadapi kenaikan sebesar $20,03 \%$. Pada siklus I tiap tiap- tiap penanda belum menggapai skor kriteria kebercapaianan minimum (75\%). Pada siklus II totalitas penanda telah menggapai skor kriteria keberasilan minimum (75\%). Periperihal tersebut meyakinkan kalau pelaksanaan model pendidikan kooperatif jenis make a match bisa tingkatkan kegiatan belajar siswa kelas XII C OTKP Sekolah Menengah Kejuruan (SMK) Negeri 1 Singaraja tahun ajaran 2019/2020.

Bersumber pada capaian riset serta ulasan terpaut dengan pelaksanaan model pendidikan kooperatif jenis make a match buat tingkatkan kegiatan belajar siswa kelas XII C OTKP Sekolah Menengah Kejuruan (SMK) Negeri 1 Singaraja, hingga bisa ditarik anjuran, ialah guru bisa mempraktikkan model pendidikan kooperatif jenis make a match pada modul pendidikan yang lain sebab model pendidikan ini teruji tingkatkan kegiatan belajar siswa. Setelah itu, guru diharapkan lebih menekankan pada kegiatan lisan paling utama kegiatan bertanya supaya keahlian berfikir kritis siswa bertambah sehingga mendukung terbentuknya mutu pendidikan yang baik.

\section{DAFTAR PUSTAKA}

Hamalik, O. (2001). Proses Belajar Mengajar. Jakarta: Bumi Aksara.

Huda, M. (2014). Model-model Pengajaran dan Pembelajaran. Yogyakarta: Pustaka Belajar.

Lie, A. (2002). Cooperative Learning. Jakarta: Gramedia Widiasarana Indonesia.

Mulyasa, E. (2009). Kurikulum Tingkat Satuan Pendidikan Sebuah Panduan. Bandung: PT. Remaja Rosdakarya.

Ningtyas, E. S., \& Wuryani, E. (2017). Penerapan Model Pembelajaran Kooperatif (Cooperative Learning) Tipe Make-A Match Berbantuan Media Komik Interaktif Untuk Meningkatkan Aktivitas Belajar dan Capaian Belajar IPS. Jurnal Pendidikan Surya Edukasi (JPSE), 3(1), 66-67. 
Nurhabibah, \& Alexon. (2017). Penerapan Model Cooperatif Learning Tipe Make A Match Untuk Meningkatkan Aktivitas Pembelajaran Matematika (PTK Siswa Kelas IVA SD Negeri 81 Kota Bengkulu). Jurnal Triadik, 16(2), 44-52.

Paneo, F. R. (2019). Upaya Meningkatkan Aktivitas Belajar IPS Melalui Model Pembelajaran Make A Match Pada Siswa Kelas VIII SMP Negeri 2 Taluditi Tahun Ajaran 2017/2018. Jurnal IImu Pendidikan Nonformal Aksara, 1(2530).

Rifa'i, M. H. (2018). Penerapan Reward Dalam Peninggian Motivasi Belajar Siswa Pada Mata Pelajaran Fikih Kelas VIII di MTs Sunan Kalijogo Malang. Universitas Islam Negeri Maulana Malik Ibrahim.

Suatnaya, P. M. (2015). Dampak Model Pembelajaran Kooperatif Make A Match Berbantuan Media Benda Asli Terhadap Capaian Belajar Matematika Siswa Kelas IV Semester Ganjil di SD Negeri Pemaron, Kecamatan Buleleng Tahun Ajaran 2014/2015. Jurnal Mimbar PGSD Undiksha, 8(3), 1-12.

Sugiyono. (2015). Tata Cara Riset Pendidikan. Bandung: Alfabeta.

Zakiah, I. R., Prasetyo, K. H., \& Astutiningtyas, E. L. (2019). Meningkatkan Aktivitas dan Capaian Belajar Melalui Pembelajaran Kooperatif Tipe Make A Match. Mathematics Education Journal, 1(2), 1-9. 